九州大学学術情報リポジトリ

Kyushu University Institutional Repository

\title{
Preparation of Anti-fragrant Monoclonal Antibodies by the Rat Lymph Node Method and Their Characterization Using Enzyme-linked Immunosorbent Assay
}

\section{Ohashi, Shintaro}

Laboratory of Food Analysis, Division of Food Biotechnology, Department of Bioscience and Biotechnology, Graduate School of Bioresource and Bioenvironmental Sciences, Kyushu University

\section{Nagatomo, Kazutaka}

Laboratory of Food Analysis, Division of Food Biotechnology, Department of Bioscience and Biotechnology, Graduate School of Bioresource and Bioenvironmental Sciences, Kyushu University

\section{Miyamoto, Koichiro}

Program of Food Science and Technology, Course of Applied Biological Science, Department of Bioresource and Bioenvironment, School of Agriculture, Kyushu University

Toko, Kiyoshi

Graduate School of Information Science and Electrical Engineering, Kyushu University

他

https://doi.org/10.5109/17808

出版情報: 九州大学大学院農学研究院紀要. 55 (1)，pp.91-96，2010-02-26. Faculty of Agriculture， Kyushu University

バージョン :

権利関係 : 


\title{
Preparation of Anti-fragrant Monoclonal Antibodies by the Rat Lymph Node Method and Their Characterization Using Enzyme-linked Immunosorbent Assay
}

\author{
Shintaro OHASHI ${ }^{1}$, Kazutaka NAGATOMO ${ }^{1}$, Koichiro MIYAMOTO ${ }^{2}$, \\ Kiyoshi TOKO ${ }^{3}$, Norio MIURA ${ }^{4}$ and Kiyoshi MATSUMOTO* \\ Laboratory of Food Analysis, Division of Food Biotechnology, Department of Bioscience and \\ Biotechnology, Faculty of Agriculture, Kyushu University, \\ Fukuoka 812-8581, Japan \\ (Received October 23, 2009 and accepted November 19, 2009)
}

\begin{abstract}
In the food and beverage industries there is a great demand for a sensitive and easy detection system of fragrant compounds in order to ensure product quality control and to avoid contamination. Benzaldehyde (BZ) and furfural (FF) are typical fragrant compounds for peach-flavored beverages, and methyl anthranilate (MA) is a typical flavor of grape beverages. For sensitive detection of these flavors by immunoreaction, we prepared monoclonal antibodies against $\mathrm{BZ}, \mathrm{FF}$ and $\mathrm{MA}$ by using the rat lymph node method. The antibody for BZ had high selectivity toward BZ compared with other fragrant compounds and high affinity with an affinity constant of $1.9 \times 10^{6} \mathrm{M}^{-1}$. The limit of detection (LOD) of BZ by indirect competitive ELISA (icELISA) was $0.6 \mathrm{ng} \mathrm{mL}^{-1}$. For FF, anti-FF mAb had high selectivity toward $\mathrm{FF}$ and high affinity constant of $2.5 \times 10^{4} \mathrm{M}^{-1}$. The LOD of $\mathrm{FF}$ by ic-ELISA was $100 \mathrm{ng} \mathrm{mL}^{-1}$. For MA, anti-MA mAb had high selectivity toward $\mathrm{MA}$ and high affinity constant of $1.3 \times 10^{5} \mathrm{M}^{-1}$. The LOD of MA by ic-ELISA was $200 \mathrm{ng} \mathrm{mL}^{-1}$. These monoclonal antibodies were suitable for detection of very small amounts of fragrant compounds in rinsed water of beverage industries.
\end{abstract}

\section{INTRODUCTION}

In beverage industries, automated bottle-filling production lines are employed at a high-speed filling-capacity, and consequently several tons of beverages are filled in a single stretch into bottles, cans or tetrapacks. The same bottle-filling production line is used routinely for various beverages of widely different aromas and flavors ranging from mineral water to fruit juices, coffee, etc. The production line must be free from contaminants before changing between different beverages. In particular, the line must be ultra-free from characteristic fragrant molecules. Excessive cleaning and/or rinsing cycles with the use of medium-hot water are applied to avoid failures. Close monitoring of the presence of trace amounts of fragrant compounds in cleaning discharges will simplify the cleaning process and will ultimately cut the production cost and time. Usually human odor-specialists are employed to detect the presence of trace amounts of fragrant compounds in cleaning process, but this occasionally involves failure. Thus, novel analytical systems allowing rapid and automated routine detection of trace amounts of low molecular weight fragrant are

Laboratory of Food Analysis, Division of Food Biotechnology, Department of Bioscience and Biotechnology, Graduate School of Bioresource and Bioenvironmental Sciences, Kyushu University

${ }^{2}$ Program of Food Science and Technology, Course of Applied Biological Science, Department of Bioresource and Bioenvironment, School of Agriculture, Kyushu University

${ }^{3}$ Graduate School of Information Science and Electrical Engineering, Kyushu University, Fukuoka, 819-0395, Japan

Art, Science and Technology Center for Cooperative Research, Kyushu University, Kasuga, Fukuoka, 816-8580, Japan

* Corresponding author (E-mail: kmatsu@agr.kyushu-u.ac.jp) indispensable to the food and beverage industry in order to ensure high quality of bottled beverages and avoid contamination of different flavors. Benzaldehyde and furfural are the most popular peach flavors and methyl anthranilate is one of the grape flavors used in the beverage industries. These flavors have relatively low threshold levels and sometimes cause problem after changing between different beverages.

Conventional chromatographic and spectroscopic methods coupled to selective detectors (mass spectrometer, electrochemical and flame photometric detectors) were established for detection and quantification of such small molecular organic compounds with high sensitivity. However, these methods involve laboratory-base bulky instruments and labor-intensive sample pre-concentrations by orders of magnitude to reach detectable amounts of analytes (Kazemifard et al., 2002; AlbalaHurtado et al., 1997; Vinas et al., 1993). Immunological methods are proven analytical tools for highly sensitive and selective determination of target analytes and involve no preliminary purification procedure (Luppa et al., 2001; Mallat et al., 2000; Kurita et al., 2006; Ngundi et al., 2005). A number of immunoassay methods, such as enzyme-linked immunosorbent assay (ELISA), fluorescence, chemiluminescence, and amperometric immunoassay methods, have been developed to transform the specific immunoaffinity interaction into a measurable physical response. However, most of these methods are highly disadvantageous, because they imply labeling of either antigen or antibody, long analysis times for $c a$. 2-6 h, extensive sample handling, and/or bulky and expensive instrumentation. In order to overcome the requirements of continuous real-time monitoring of target analyte, we have focused on the development of highly sensitive surface plasmon resonance (SPR) sensing 
methods for the detection of low molecular weight (LMW) compounds using an antigen-antibody reaction (Matsumoto et al., 2005; Shankaran et al., 2006; Gobi et al., 2008, Nagatomo et al., 2009a). For highly sensitive detection of LMW compounds by SPR immunosensor, antibodies with high selectivity and affinity are exclusively required. For this purpose, we have engaged in producing polyclonal and monoclonal antibodies (Sakai et al., 2003; Matsumoto et al., 2005; Nagatomo et al., 2009b). Recently, a novel method was developed for preparation of rat monoclonal antibodies by using rat medial iliac lymph node cells (Kishoro et al., 1995; Sado et al., 1995; Sado et al., 2006).

In order to develop highly sensitive SPR immunosensors, we firstly prepared anti-benzaldehyde, anti-furfural and anti-methyl anthranilate monoclonal antibodies by using medal iliac node cells and characterized their properties by using solid-phase enzyme-linked immunosorbent assay (ELISA).

\section{MATERIALS AND METHODS}

\section{Materials and Apparatus}

Bovine serum albumin (BSA), $N$-hydroxysuccinimide (NHS), o-phenylenediamine (o-PD), 1-ethyl-3-(3dimethyl aminopropyl) carbodiimide (EDC), disodium $p$-nitrophenylphosphate ( $p$-NPP), 2-furan carboxylic acid and gelatin were obtained from Nacalai Tesque, Inc. (Kyoto, Japan). Ovalbumin (OVA, Grade VI), guanidine hydrochloride and 4-carboxybenzaldehyde (CBZ, >98\%), benzaldehyde (BZ, >99\%), 1-methyl 2-aminoterephthalate (MAT), alkaline phosphatase labeled anti-rabbit immunogloblin G (ALP labeled anti-rabbit IgG), ALP labeled anti-rat IgG, 5-fromyl 2-furancarboxylic acid (FFC) were obtained from Sigma (St. Louis, MO, USA). 2,4-Dinitrophenylhydrazine (DNPH) and furfural (FF) were from Kanto Chemical Co., Inc. (Tokyo, Japan). Mariculture keyhole limpet hemocyanin (KLH) and Concholepas concholepas hemocyanin (CCH) were from Pierce (Rodkford, IL, USA). GIT medium and methyl anthranilate (MA) were obtained from Wako Pure Chemicals Ind., Ltd. (Osaka, Japan). Freund's complete adjuvant was obtained from Difco (Detroit, MI, USA). Sevofrane was from Maruishi Pharmaceutical Co. Ltd. (Osaka, Japan). Fetal bovine serum (FBS) and BM-condimed H1 were from Gibco (OK, USA) and Roche (Basel, Switzerland), respectively. Horse radish peroxidase labeled polyclonal rabbit anti-rat immunoglobulin G (HRP labeled anti-rat IgG) was from Daco Japan Co. (Tokyo, Japan). The HiTrap Protein G column and PD-10 column were purchased from GE healthcare UK Ltd. (Amersham Place, Little Chalfont, England). Isotyping test kit (RMT1) was from AbD serotec (Cosmo Bio, Tokyo, Japan). All other reagents were of analytical-reagent grade. All buffer solutions were prepared using water purified with a Milli-Q filter (Millipore, Bedford, MA, USA).

ELISA measurements were performed using 96-well immunoplates (NUNC, No. 446612, Roskilde, Denmark) and a microplate reader (Wallac 1420, Perkin Elmer Life
Science Japan, Tokyo, Japan). Spectrophotometric measurements were performed using a Shimadzu Multi Spec 1500 (Kyoto, Japan).

\section{Preparation of fragrant analog-protein conjugate}

CBZ-KLH conjugate: An ice-cooled solution of $1.8 \mathrm{mg}(12 \mu \mathrm{mol})$ of $\mathrm{CBZ}$ in $1 \mathrm{~mL}$ dioxane was stirred with $2.3 \mathrm{mg}(20 \mu \mathrm{mol}) \mathrm{NHS}, 50 \mathrm{mg} \mathrm{Na}_{2} \mathrm{SO}_{4}$ and later $34 \mathrm{mg}(177 \mu \mathrm{mol})$ EDC over night at room temperature (RT). The resulting mixture was centrifuged and the supernatant solution was slowly added to a solution of $5 \mathrm{mg} \mathrm{KLH}$ in $1 \mathrm{~mL}$ borate buffer (12.5 mM, pH 8.0). The addition of the supernatant solution was divided in three portions (180 $\mu \mathrm{L}$ each) with 30 min interval. After incubating it at $\mathrm{RT}$ for $3 \mathrm{~h}$, the reaction mixture was dialyzed against borate buffer (12.5 mM, pH 8.0) for one days (three times change) at $5{ }^{\circ} \mathrm{C}$ and was then lyophilized. Condensing a chromophoric compound, DNPH, with aldehydes was used to estimate the number of BZ haptens per CBZ-KLH conjugate. Control experiments using the initial KLH protein had been carried out to corroborate the number of haptens determined. The hydrazone adduct has an absorbance maximum around $380 \mathrm{~nm}$ with a molar extinction coefficient of $22,000 \mathrm{M}^{-1} \mathrm{~cm}^{-1}$ (DalleDonne et al., 2003; Levine et al., 1990), and the average number of BZ haptens per CBZ-KLH unit was determined to be 24.2. The CBZ-OVA conjugates were also prepared by almost the same way with CBZ-KLH conjugates, and the average number of BZ haptens per CBZOVA unit was 1.8.

FFC-KLH conjugate: FFC-KLH conjugates were prepared by almost the same way with CBZ-KLH conjugates except the starting amount of FFC (3.36 mg; $24 \mu \mathrm{mol})$. FFC-OVA conjugates were also prepared as above. The average number of FF haptens per FFC-KLH unit was estimated to be $c a .50$.

MAT-CCH conjugate: MAT (2.3 mg; $12 \mu \mathrm{mol}$ ) was dissolved in $1 \mathrm{~mL}$ of DMF and $50 \mathrm{mg} \mathrm{Na}_{2} \mathrm{SO}_{4}, 23 \mathrm{mg} \mathrm{NHS}$ and $34 \mathrm{mg}$ EDC were added at $4{ }^{\circ} \mathrm{C}$ under stirring for $2 \mathrm{~h}$ and then the mixture was stirred overnight at RT. The resulting mixture was centrifuged and the supernatant solution was slowly added to a solution of $50 \mathrm{mg} \mathrm{CCH}$ in $4 \mathrm{~mL}$ borate buffer (12.5 mM, pH 8.0) containing $50 \mathrm{mg}$ $\mathrm{Na}_{2} \mathrm{CO}_{3}$. After stirring overnight at $\mathrm{RT}$, the reaction mixture was dialyzed against borate buffer (12.5 mM, pH 8.0) for one day (three times change) at RT and was then lyophilized. The conjugation of MAT to $\mathrm{CCH}$ was confirmed by UV spectrum. The MAT-OVA conjugates were prepared by using the Fmoc method (Louis et al., 1972; Louis, 1987), and the average number of MA haptens per MAT-OVA unit was 8.2.

\section{Immunization of rats}

Rats, anesthetized with sevofrane, were immunized with fragrant analog-protein conjugates according to the following procedures. Conjugates dissolved in phosphate buffered saline (PBS, $1 \mathrm{mg} \mathrm{mL}^{-1}$ ) were thoroughly emulsified with an equal volume of Freund's complete adjuvant in two $2-\mathrm{mL}$ glass syringes with a three-way stopcock. After emulsification was completed, the emulsion 
was sucked in one $\mathrm{ml}$ of plastic syringe attached with $25 \mathrm{G} \times 1$ " needle.

Nine-week-old female WKY rats (Charles River Japan, Inc., Yokohama) were injected intramuscularly at the right and left tail base with the prepared emulsion (0.2 mL in total). Rats were kept in plastic cages containing wood shavings for bedding. All animal experiments were conducted under the control of the guideline for Animal Experiment in Kyushu University and the Law (No. 105) and Notification (No. 6) of the Government.

The rats were bled every week from tail veins after the immunization, and the antisera were collected by centrifugation of the blood samples. The antisera were tested by direct-ELISA. Ninety-six-well immunoplates were coated with $100 \mu \mathrm{L}$ of fragrant analog-protein conjugates (immunogen, $10 \mu \mathrm{g} \mathrm{mL}^{-1}$ in PBS) overnight at RT. The plates were then treated with $150 \mu \mathrm{L}$ of $1 \%$ gelatin for $1 \mathrm{~h}$ at $\mathrm{RT}$, and reacted with antisera at nine different dilutions (1/100-1/25,600 in PBS), which were added to the wells (100 $\mu \mathrm{L}$ to each well) and incubated for $1.5 \mathrm{~h}$ at RT. For antisera taken from the immunized rats with CBZ-KLH or FFC-KLH, the solution of HRP labeled anti-rat IgG (1/1000 dilution in PBS) was added $(100 \mu \mathrm{L}$ to each well) and incubated for $1 \mathrm{~h}$ at RT. Then, $150 \mu \mathrm{L}$ of the substrate solution $\left(0.4 \mathrm{mg} \mathrm{mL}^{-1}\right.$ of $o-\mathrm{PD}$ and $0.4 \mu \mathrm{L}$ $\mathrm{mL}^{-1}$ of $30 \% \mathrm{H}_{2} \mathrm{O}_{2}$ in PBS) was added to each well and incubated for $30 \mathrm{~min}$ at room temperature. After the reaction, $50 \mu \mathrm{L}$ of $3 \mathrm{M}$ sulfuric acid was added to terminate the enzyme reaction, and then the absorbance at $490 \mathrm{~nm}$ was measured. For antisera from MAT-CCH, the solution of ALP labeled anti-rat IgG (1/2000 dilition in PBS) was added (100 $\mu$ L to each well) and incubated for $45 \mathrm{~min}$ at RT. After the incubation, $100 \mu \mathrm{L}$ of the substrate solution ( $2 \mathrm{mg} \mathrm{mL}^{-1}$ of $p-\mathrm{NPP}$ in $50 \mathrm{mM}$ carbonate buffer, $\mathrm{pH} 7.4$, containing $0.1 \mathrm{mM} \mathrm{Zn^{2+ }}$ and $1 \mathrm{mM} \mathrm{Mg}^{2+}$ ) was added to each well and incubated for $30 \mathrm{~min}$ at RT, and absorbance at $405 \mathrm{~nm}$ was measured. The plates were rinsed three times with PBS containing 0.05\% Tween 20 (PBST) at each step. The rats were bled without boost injection for 2-3 weeks for obtaining both iliac lymph cells and polyclonal antibodies.

\section{Cell fusion}

A mouse myeloma cell line, Sp2/0-Ag14 (Dainihon Sumitomo Pharmacy), was used for cell fusion. The procedures were almost the same as our previous paper (Nagatomo et al., 2009b).

\section{Serum antibody titers and screening assay}

Anti-BZ antibody: The supernatants were screened for production of BZ-antibody by indirect ELISA. ELISA plates were coated with $100 \mu \mathrm{L}$ of CBZ-OVA conjugate $\left(10 \mu \mathrm{g} \mathrm{mL}^{-1}\right.$ ) overnight at RT. The plates were washed and blocked with $1 \%$ gelatin for $1 \mathrm{~h}$ at RT. The plates were washed and $50 \mu \mathrm{L}$ of the supernatant of each cultured well were added to each well. One series of experiments was performed to check the association of supernatants (antibodies) to the coating conjugates. The other series of experiments was performed to check whether the supernatants (antibodies) will be inhibited with free
BZ as follows: after the addition of supernatant, $50 \mu \mathrm{L}$ of BZ solution was added at the final concentration of $50 \mu \mathrm{g}$ $\mathrm{mL}^{-1}$. The subsequent procedures for both experiments were almost the same as Section of immunization of rat. The cells, which were confirmed the production of antiBZ antibody and the ability of association toward free BZ, were suspended in GIT medium containing 10\% FBS (SGIT). The suspensions were subjected to the limit dilution methodology, and the screening and cloning were repeated for two times, and then monoclonal antibody producing hybridomas were established. The hybridomas were cultured in SGIT, and the supernatant was collected and purified with protein G column and PD-10 column according to the procedures recommended by the manufacturers. The isotype of the monoclonal antibody was IgG2a.

Anti-FF antibody: The supernatants were screened for production of anti-FF antibody by indirect ELISA. The procedures were almost the same as above except using FFC-OVA conjugate as a solid phase protein. The isotype of the monoclonal antibody was IgG1.

Anti-MA antibody: The screening procedures were almost the same as above except using MAT-OVA conjugate as a solid phase protein. The isotype of the monoclonal antibody was IgG2b.

\section{Indirect competitive ELISA (ic-ELISA) for fra- grant compounds}

IC-ELISAs for BZ (or FF): Ic-ELISAs for BZ (or FF) were performed as follows. Ninety-six-well immunoplates were coated with $100 \mu \mathrm{L}$ of CBZ-OVA conjugate, $1 \mu \mathrm{g} \mathrm{mL}^{-1}$ in PBS (or FFC-OVA conjugate, $1 \mu \mathrm{g} \mathrm{mL} \mathrm{m}^{-1}$ ), over night at RT. The following day, the plates were washed three times with PBST and treated with $150 \mu \mathrm{L}$ of $1 \%$ gelatin for $1 \mathrm{~h}$ at RT. The plates were washed three times with PBST, reacted with $100 \mu \mathrm{L}$ of the equivalent mixtures of anti-BZ monoclonal antibody (anti-BZ

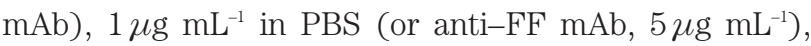
and serially diluted $\mathrm{BZ}$ (or FF) for $1.5 \mathrm{~h}$ at RT. The plates were washed again three times with PBST, and the solution of HRP labeled anti-rat IgG (1/1000 dilution in PBS) was added (100 $\mu \mathrm{L}$ to each well) and incubated for $1 \mathrm{~h}$ at RT. The plates were washed again, and $150 \mu \mathrm{L}$ of the substrate solution $\left(0.4 \mathrm{mg} \mathrm{mL}^{-1}\right.$ of $O-\mathrm{PD}$ and $0.4 \mu \mathrm{L} \mathrm{mL}^{-1}$ of $30 \% \mathrm{H}_{2} \mathrm{O}_{2}$ in PBS) was added to each well and incubated for $30 \mathrm{~min}$ at RT. After the reaction, $50 \mu \mathrm{L}$ of $3 \mathrm{M}$ sulfuric acid was added to terminate the enzyme reaction, and then the absorbance at $490 \mathrm{~nm}$ was measured.

Ic-ELISAs for MA: Ninety-six-well immunoplates were coated with $100 \mu \mathrm{L}$ of MAT-OVA conjugate, $3 \mu \mathrm{g}$ $\mathrm{mL}^{-1}$ in PBS, over night at RT. The following day, the plates were washed three times with PBST and treated with $150 \mu \mathrm{L}$ of $1 \%$ gelatin for $1 \mathrm{~h}$ at RT. The plates were washed three times with PBST, reacted with $100 \mu \mathrm{L}$ of the equivalent mixtures of anti-MA monoclonal antibody (anti-MA mAb), $0.4 \mu \mathrm{g} \mathrm{mL}^{-1}$ in PBS, and serially diluted $\mathrm{MA}$ for $1.5 \mathrm{~h}$ at RT. After washing with PBST the solution of ALP labeled anti-rat IgG (1/2000 dilution in PBS) was added (100 $\mu \mathrm{L}$ to each well) and incubated for 
$45 \mathrm{~min}$ at RT. After the incubation, $100 \mu \mathrm{L}$ of the substrate solution ( $2 \mathrm{mg} \mathrm{mL}^{-1}$ of $p-\mathrm{NPP}$ in $50 \mathrm{mM}$ carbonate buffer, $\mathrm{pH} 7.4$, containing $0.1 \mathrm{mM} \mathrm{Zn^{2+ }}$ and $1 \mathrm{mM} \mathrm{Mg}^{2+}$ ) was added to each well and incubated for $30 \mathrm{~min}$ at RT, and absorbance at $405 \mathrm{~nm}$ was measured.

\section{Avidity of anti-fragrant mAb to various kinds of fragrant compounds}

The avidity of anti-fragrant mAb to fragrant compounds was investigated by ic-ELISAs using each fragrant analog-OVA conjugate as a coating antigen-protein conjugate. The ELISA procedures were the same as described in Section of ic-ELISA for fragrant compounds. The $\mathrm{IC}_{50}$ was defined as the concentration of added fragrant compounds that yield 50\% inhibition compared with no inhibition (100\%). Molar cross-reactivities were related to each target fragrant compound (100\%); namely, all molar cross-reactivities were determined in relation to each fragrant standard inhibition curve. The molar cross-reactivity of each derivative was calculated according to Weiler's equation (Weiler and Zenk, 1976):

$$
\mathrm{CR}=\left(\mathrm{IC}_{50} * / \mathrm{IC}_{50}\right) \times 100
$$

where CR is molar cross-reactivity (\%), $\mathrm{IC}_{50} *$ is the $\mathrm{IC}_{50}$ of each standard $(\mathrm{M})$, and $\mathrm{IC}_{50}$ is the $\mathrm{IC}_{50}$ of fragrant compounds (M).

\section{Data analysis}

Experimental values obtained from indirect competitive assays were converted into inhibition values $\left(\% \mathrm{~B} / \mathrm{B}_{0}\right)$ by using following equation:

$\% \mathrm{~B} / \mathrm{B}_{0}=100 \times \mathrm{B} / \mathrm{B}_{0}$

In ic-ELISA, $\mathrm{B}$ is the absorbance value for each standard and $\mathrm{B}_{0}$ is the absorbance value resulting from a zero dose standard (blank value). Curve fitting of standard curves was performed by use of following equation (Holthues et al., 2005):

$$
\mathrm{Y}=100 /\left[1+(\mathrm{x} / \mathrm{c})^{\mathrm{b}}\right]
$$

where $\mathrm{c}$ is the midpoint, $\mathrm{b}$ is the slope of the curve, and $X$ is the standard concentration. The limit of detection (LOD) was calculated as three times the standard deviation of a blank value, following IUPAC rules.

\section{RESULTS AND DISCUSSION}

\section{Establishment of monoclonal antibody hybridoma}

Anti-BZ hybridoma: The establishment of the hybridoma cells which produce monoclonal anti-BZ antibody (anti-BZ mAb) was one cell of 84 fusion positive cells. The inhibition profile of anti-BZ mAb by the ic-ELISA is shown in Fig. 1 along with that of rat anti-BZ-KLH polyclonal antibody (anti-BZ pAb). As shown in Fig. 1, the anti-BZ mAb showed the LOD of 0.6 ng $\mathrm{mL}^{-1}$ (ppb) toward BZ. This sensitivity is much higher than that using polyclonal antibody. The affinity constants between free BZ and anti-BZ antibodies (monoclonal and polyclonal) were also estimated by using Seligman's method (Seligman, 1994) using the data of Fig. 1. The evaluated values were $\mathrm{K}_{\mathrm{A}}=1.9 \times 10^{6} \mathrm{M}^{-1}$ and $\mathrm{K}_{\mathrm{A}}=1.3 \times 10^{3} \mathrm{M}^{-1}$ for anti$\mathrm{BZ} \mathrm{mAb}$ and anti-BZ pAb, respectively.
Anti-FF hybridoma: The establishment of the hybridoma cells which produce monoclonal anti-FF antibody (anti-FF mAb) was two cells of 90 fusion positive cells. We denoted the hybridomas as FF-mAb1 cell and $\mathrm{FF}-\mathrm{mAb} 2$ cell. We selected the FF-mAb1 hybridoma as a best one in consideration of relatively strong affinity to solid phase FFC-OVA and strong affinity to free FF. The inhibition profile of anti-FF mAb1 by the ic-ELISA is shown in Fig. 2 along with that of rat anti-FF-KLH polyclonal antibody (anti-FF pAb). As shown in Fig. 2, the anti-FF mAb1 showed the LOD of $0.1 \mu \mathrm{g} \mathrm{mL}^{-1}(0.1 \mathrm{ppm})$ toward FF. Although the LOD of anti-FF mAb toward $\mathrm{FF}$ was a little worse than that of anti-FF pAb, the affinity constant between free $\mathrm{FF}$ and anti-FF mAb1 $\left(\mathrm{K}_{\mathrm{A}}=\right.$ $\left.2.5 \times 10^{4} \mathrm{M}^{-1}\right)$ was better than that between free $\mathrm{FF}$ and anti-FF pAb $\left(\mathrm{K}_{\mathrm{A}}=2.1 \times 10^{3} \mathrm{M}^{-1}\right)$. These results (LODs and affinity constants) seemed to reflect that the percent inhibition in low concentration region $(0.1 \mathrm{ppb}-0.1 \mathrm{ppm})$ with polyclonal antibody changed moderately whereas that of monoclonal antibody in $0.1 \mathrm{ppm}$ level changed sharply.

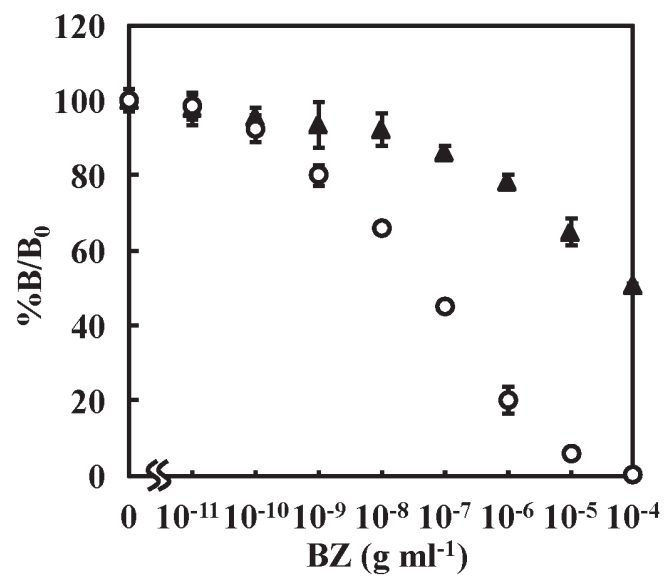

Fig. 1. Standard curve of $B Z$ in indirect competitive ELISA. The results are shown as mean values. Symbols are as follows: $\boldsymbol{\Delta}$, polyclonal antibody $(\mathrm{n}=3) ; \bigcirc$, monoclonal antibody $(\mathrm{n}=3)$

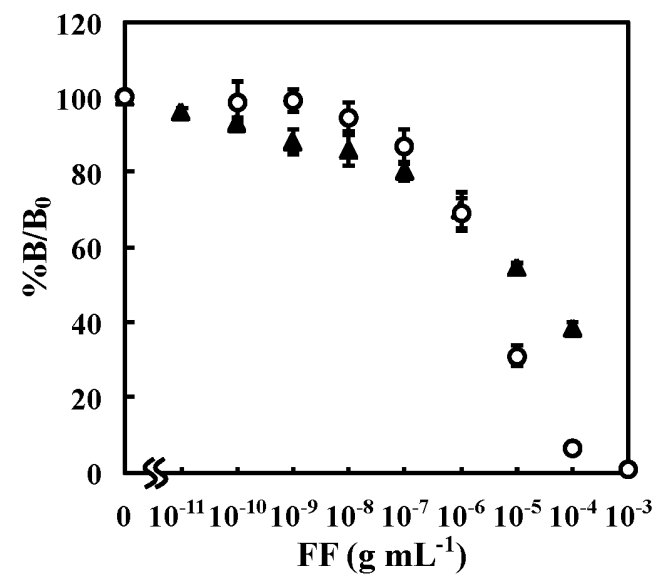

Fig. 2. Standard curve of FF in indirect competitive ELISA. The results are shown as mean values. Symbols are as follows: $\boldsymbol{\Delta}$, polyclonal antibody $(\mathrm{n}=3) ; \bigcirc$, monoclonal antibody $(\mathrm{n}=6)$ 
We used FF-mAb1 hybridoma hereafter.

Anti-MA hybridoma: The establishment of the hybridoma cells which produce monoclonal anti-MA antibody (anti-MA mAb) was three cells of 1370 fusion positive cells. We denoted the hybridomas as MA-mAb1 cell to MA-mAb3 cell. We selected the MA-mAb1 hybridoma as a best one in consideration of relatively strong affinity to solid phase MAT-OVA and strong affinity to free MA. The inhibition profile of anti-MA mAb1 by the ic-ELISA is shown in Fig. 3 along with that of rat anti-MAT-CCH polyclonal antibody (anti-MA pAb). As shown in Fig. 3, the anti-MA mAb1 showed the LOD of $0.2 \mu \mathrm{g} \mathrm{mL}-1$ (0.2 ppm) toward MA. This sensitivity is much higher than that of polyclonal antibody. We used MA-mAb1 hybridoma hereafter. The affinity constants between free MA and anti-MA antibodies (monoclonal and polyclonal) were also estimated by using Seligman's method using the data of Fig. 3. The evaluated values were $\mathrm{K}_{\mathrm{A}}=1.3 \mathrm{X}$ $10^{5} \mathrm{M}^{-1}$ and $\mathrm{K}_{\mathrm{A}}=9.8 \times 10^{2} \mathrm{M}^{-1}$ for anti-MA mAb1 and antiMA pAb, respectively.

\section{Avidity of anti-fragrant mAbs to various kinds of fragrant compounds}

The avidity of the prepared antibodies (anti-fragrant mAbs) to various compounds other than target fragran compound was evaluated by ic-ELISAs. The coating antigen-protein conjugate was each fragrant analogOVA conjugate. Midpoints $\left(\mathrm{IC}_{50}\right)$ and molar cross-reactivity for BZ are listed in Table 1. As shown in Table 1, the anti-BZ mAb showed high selectivity toward relating compounds (or fragrant compounds) except vanillin (20.7\%) and furfural (14.8\%). CBZ, the starting compound of immunogen, showed the cross reactivity of $c a$. $58 \%$ and this compound is not contained in food beverage. Benzoic acid, a food preservative, did not show any affinity. Overall, the anti-BZ mAb seemed to be valuable for selective detection of target fragrant compound (BZ).

Midpoints $\left(\mathrm{IC}_{50}\right)$ and molar cross-reactivity for $\mathrm{FF}$ are listed in Table 2. As shown in Table 2, very small or

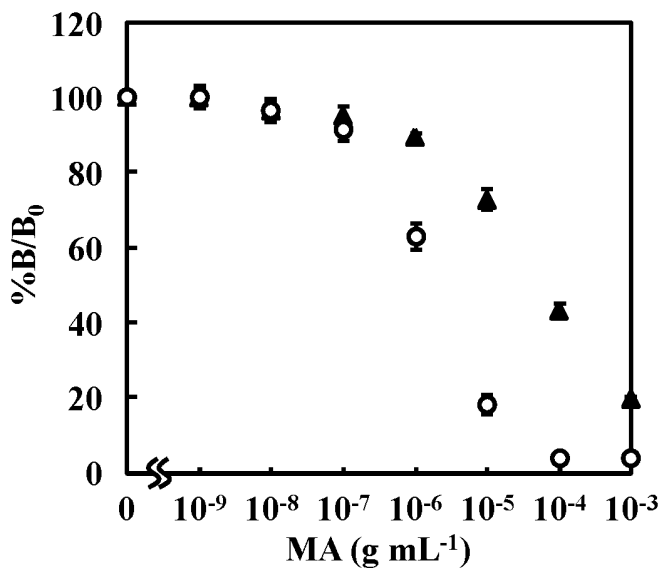

Fig. 3. Standard curve of MA in indirect competitive ELISA. The results are shown as mean values. Symbols are as follows: $\boldsymbol{\Delta}$, polyclonal antibody $(n=3) ; \bigcirc$, monoclonal antibody $(n=6)$ almost no avidity were shown with BZ (13.9\%), 2-furancarboxylic acid $(<1 \%)$, vanillin $(<1 \%)$, benzoic acid $(<1 \%)$, and $\gamma$-undecalactone (none). FFC, the starting compound of immunogen, showed the cross reactivity of ca. $76 \%$ and this compound is not contained in food beverage. From these results, we judged the anti-FF mAb1 is valuable.

Midpoints $\left(\mathrm{IC}_{50}\right)$ and molar cross-reactivity for MA are also listed in Table 3. As shown in Table 3, the antiMA mAb1 showed rather high selectivity toward relating

Table 1. Cross reactivities of anti-BZ mAb for BZ relevant compounds

\begin{tabular}{ccc}
\hline Compound & $\mathrm{IC}_{50}(\mathrm{M})$ & $\begin{array}{c}\text { Cross } \\
\text { reactivity } \\
(\%)\end{array}$ \\
\hline benzaldehyde (BZ) & $2.50 \times 10^{-6}$ & 100 \\
4-carboxy benzaldehyde & $4.30 \times 10^{-6}$ & 58.1 \\
vanilin & $1.20 \times 10^{-5}$ & 20.7 \\
furfural (FF) & $1.70 \times 10^{-5}$ & 14.8 \\
4-formypheoxy acetic acid & $2.00 \times 10^{-5}$ & 12.0 \\
4-methoxy benzaldehyde & $8.40 \times 10^{-5}$ & 3.00 \\
methyl anthranilate (MA) & No inhibition & - \\
5-formyl 2-furancaroxylic acid & No inhibition & - \\
r-undecalactone & No inhibition & - \\
benzoic acid & No inhibition & - \\
\hline
\end{tabular}

Table 2. Cross reactivities of anti-FF mAb1 for FF relevant compounds

\begin{tabular}{ccc}
\hline Compound & $\mathrm{IC}_{50}(\mathrm{M})$ & $\begin{array}{c}\text { Cross } \\
\text { reactivity } \\
(\%)\end{array}$ \\
\hline furfural (FF) & $4.53 \times 10^{-5}$ & 100 \\
5-formyl-2-furancarboxylic acid & $6.00 \times 10^{-5}$ & 75.5 \\
benzaldehyde (BZ) & $3.26 \times 10^{-4}$ & 13.9 \\
2-furancarboxylic acid & $4.70 \times 10^{-3}$ & $<1$ \\
vanilin & $5.23 \times 10^{-3}$ & $<1$ \\
benzoic acid & $6.06 \times 10^{-3}$ & $<1$ \\
$\gamma$-undecalactone & No inhibition & - \\
\hline
\end{tabular}

Table 3. Cross reactivities of anti-MA mAb1 for MA relevant compounds

\begin{tabular}{ccc}
\hline Compound & $\mathrm{IC}_{50}(\mathrm{M})$ & $\begin{array}{c}\text { Cross } \\
\text { reactivity } \\
(\%)\end{array}$ \\
\hline methyl anthranilate (MA) & $1.91 \times 10^{-5}$ & 100 \\
methyl 2-amino-3-carboxybenzoate & $4.36 \times 10^{-6}$ & 438 \\
1-methyl-2-aminoterephthalate & $2.26 \times 10^{-5}$ & 84.5 \\
$N$-methylanthranilic acid methyl ester & $2.56 \times 10^{-5}$ & 74.6 \\
o-toluic acid methyl ester & $1.29 \times 10^{-4}$ & 14.8 \\
2-aminoacetophenone & $1.30 \times 10^{-4}$ & 14.7 \\
2-aminobenzaldehyde & $1.09 \times 10^{-3}$ & 1.75 \\
anthranilic acid & $2.01 \times 10^{-3}$ & $<1$ \\
benzaldehyde (BZ) & $2.01 \times 10^{-3}$ & $<1$ \\
furfural (FF) & No inhibition & - \\
o-phenylenediamine & No inhibition & - \\
\hline
\end{tabular}


compounds (or fragrant compounds) except methyl 2-amino-3-carboxybenzoate (438\%), MAT (84.5\%) and $\mathrm{N}$-methylanthranilic acid methyl ester (74.6\%). Methyl 2-amino-3-carboxybenzoate and MAT, which have the MA skeletal structure, are not contained in food beverage. $N$-methylanthranilic acid methyl ester is a flavor of grape and its smell is almost same as MA. This means acceptable to measure $N$-methylanthranilic acid methyl ester together with MA. From these results, we judged the anti-MA mAb1 is valuable.

\section{CONCLUSIONS}

Monoclonal antibodies against BZ, FF and MA were successfully prepared by using the rat lymph node method. One hybridoma cell which produce anti-BZ antibody were produced out of 84 fusion positive cells. The anti-BZ mAb has high selectivity toward BZ compared with other fragrant compounds and high affinity constant of $1.9 \times 10^{5} \mathrm{M}^{-1}$ to BZ. The LOD of BZ by ic-ELISA was $0.6 \mathrm{ng} \mathrm{mL}^{-1}(0.6 \mathrm{ppb})$. For FF, two hybridoma cells which produce anti-FF antibody were produced out of 90 fusion positive cells. The best antibody (anti-FF mAb1) has high selectivity toward FF compared with other fragrant compounds and high affinity constant of $2.5 \times 10^{4} \mathrm{M}^{-1}$ to $\mathrm{FF}$. The LOD of FF by ic-ELISA was $100 \mathrm{ng} \mathrm{mL}^{-1}$ (100 ppb). For MA, three hybridoma cells which produce anti-MA antibody were produced out of 1370 fusion positive cells. The best antibody (anti-MA mAb1) has high selectivity toward MA compared with other fragrant compounds and high affinity constant of $1.3 \times 10^{5} \mathrm{M}^{-1}$ to MA. The LOD of MA by ic-ELISA was $200 \mathrm{ng} \mathrm{mL}^{-1}$ (200 ppb). These monoclonal antibodies were suitable for detection of very small amounts of fragrant compounds in rinsed water of beverage industries.

\section{ACKNOLEGEMENTS}

This work was partly supported by a Grant-in-Aid from the New Energy and Industrial Development Organization (NEDO), Japan.

\section{REFERENCES}

Albala-Hurtado, S., M. T. Veciana-Nogues, M. Izquierdo-Pulido, M. C. Vidal-Carou 1997 Determination of Free and Total Furfural Compounds in Infant Milk Formulas by HighPerformance Liquid Chromatography. J. Agric. Food Chem., 45: 2128-2133

Carpino, L. A., G. Y. Han 1972 The 9-Fluorenylmethoxycarbonyl Amino-Protecting Group. J. Org. Chem., 37: 3404-3409

Carpino, L. A. 1987 The 9-Fluorenylmethoxycarbonyl Family of Base-Sensitive Amino-Protecting Groups. Acc. Chem. Res., 20: $401-407$

Dalle-Donne, I., R. Rossi, D. Giustarini, A. Milzani, R. Colombo 2003 Protein carbonyl groups as biomarkers of oxidative stress. Clin. Chim. Acta, 329: 23-38

Gobi, K. V., K. Matsumoto, K. Toko, N. Miura 2008 Highly regenerable and storageable all-chemical based PEG-immunosensor chip for SPR detection of ppt levels of fragrant compounds from beverage samples. Sens. \& Instrument. Food Qual., 2: 225-233

Holthues, H., U. Pfeifer-Fukumura, I. Sound, W. Baumann 2005
Evaluation of the concept of heterology in a monoclonal antibody-based ELISA utilizing direct hapten linkage to polystyrene microtiter plates. J. Immunol. Methods, 304: 68-77

Kazemifard, A. G., D. E. Moore, A. Mohammadi 2002 Polarographic determination of benzaldehyde in benzyl alcohol and sodium diclofenac injection formulations. J. Pharm. Biomed. Anal., 30: $257-262$

Kishiro, Y., M. Kagawa, I. Naito, Y. Sado 1995 A Novel Method of Preparing Rat-Monoclonal Antibody-Producing Hybridomas by Using Rat Medial Iliac Lymph Nodee Cells. Cell Struct. Funct., 20: 151-156

Kurita, R, Y. Yokota, Y. Sato, F. Mizutani, O. Niwa 2006 On-Chip Enzyme Immunoassay of a Cardiac Marker Using a Microfluidic Device Combined with a Portable Surface Plasmon Resonance System. Anal. Chem., 78: 5525-5531

Levine, R. L., D. Garland, C. N. Oliver, A. Amici, I. Climent, A-G. Lenz, B-W. Ahn, S. Shaltiel, E. R. Stadtman 1990 Determination of Carbonyl Content in Oxidatively Modified Proteins. Methods Enzymol., 186: 464-478

Luppa, P. B., L. J. Sokoll, D. W. Chan 2001 Immunosensorsprinciples and applications to clinical chemistry. Clin. Chim. Acta, 314: 1-26

Mallat, E., D. Barcelo, C. Barzen, G. Gauglitz, R. Abuknesha 2000 Immunosensors for pesticide determination in natural waters. Trends Anal. Chem., 20: 124-132

Matsumoto, K., A. Torimaru, S. Ishitobi, T. Sakai, M. Ishikawa, K. Toko, N. Miura, T. Imato 2005 P reparation and characterization of a polyclonal antibody from rabbit for detection of trinitrotoluene by a surface plasmon resonance biosensor. Talanta, 68: $305-311$

Nagatomo, T., T. Kawaguchi, N. Miura, K. Toko, K. Matsumoto 2009a Development of a sensitive surface plasmon resonance immunosensor for detection of 2,4-dinitrotoluene with a novel oligo (ethylene glycol)-based sensor surface. Talanta, $\mathbf{7 9}$ $1142-1148$

Nagatomo, T., K. Matsumoto, N. Miura, K. Toko 2009b Preparation of Anti-2,4-dinitrotoluene Monoclonal Antibody by Using Rat Medial Iliac Lymph Node Cells and Its Characterization Using Solid Phase Enzyme-linked Immunosorbent Assay. J. Fac. Agr., Kyushu Univ., 54(1): $173-178$

Ngundi, M. M., L. C. Shriver-Lake, M. H. Moore, M.E. Lassman, F. S. Ligler, C. R. Taitt 2005 Array Biosensor for Detection of Ochratoxin A in Cereals and Beverages. Anal. Chem., 77: $148-154$

Sado, Y., M. Kagawa, Y. Kishiro, K. Sugihara, I. Naito, J. M. Seyer, M. Sugimoto, T. Oohashi, Y. Ninomiya 1995 Establishment by the rat lymph node method of epitope-defined monoclonal antibodies recognizing the six different $\alpha$ chains of human type IV collagen. Histochem. Cell Biol., 104: 267-275

Sado, Y., S. Inoue, Y. Tomono, and H. Omori 2006 Lymphcytes from Enlarged Iliac Lymph Nodes as Fusion Partners for the Production of Monoclonal Antibodies after a Signle Tail Base Immunization Attempt. Acta Histochem. Cytochem., $\mathbf{3 9}$ 89-94

Sakai T., A. Torimaru, K. Shinahara, N. Miura, T. Imato, K. Toko, and K. Matsumoto 2003 Preparation of a Polyclonal Antibody and a Bioassay for Nitroaromatic Compounds by an EnzymeLinked Immunosorbent Assay Technique and a Surface Plasmon Resonance Immunosensor. Sens. Mater., 15: 439-452

Shankaran, D. R., K. Matsumoto, K. Toko, N. Miura 2006 Development and comparison of two immunoassays for the detection of 2,4,6-trinitrotoluene (TNT) based on surface plasmon resonance. Sensors \& Actuators B, 114: 71-79

Vinas, P., C. L. Erroz, M. H. Cordoba 1993 Determination of Methyl Anthranilate and Methyl $N$-Methylanthranilate in Beverages by Liquid Chromatography with Fluorescence Detection. Chromatographia, 35: 681-684

Weiler, E. W., M. H. Zenk 1976 Radioimmunoassay for the determination of digoxin and related compounds in Digitalis lanata. Phytochem., 15: 1537-1545 